\title{
PARTIAL CHARACTERIZATION AND CLONING OF PROTEASE FROM BACILLUS
}

\author{
VALYA RAMAKRISHNAN ${ }^{1}$, YUVARANI THAMBIDURAI ${ }^{2}$, SATISH KUMAR RAJASEKHARAN ${ }^{3}$, \\ SUCHARITHA KANNAPPAN MOHANVEL ${ }^{2 *}$
}

\begin{abstract}
${ }^{1}$ Moores Cancer Center, University of California, San Diego, USA. ${ }^{2}$ Department of Biotechnology, D. G. Vaishnav College, Arumbakkam, Chennai - 600 106, Tamil Nadu, India. ${ }^{3}$ Department of Lifescience, Center for Research and Development, PRIST University, Thanjavur - 614 904, Tamil Nadu, India. Email: charusunder@gmail.com
\end{abstract}

Received: 16 April 2017, Revised and Accepted: 23 June 2017

ABSTRACT

Objective: The present research focused on amplification of protease gene from Bacillus strain which was then assessed for maximal enzyme activity.

Methods: A putative Bacillus strain was isolated from soil, inoculated into protease production media, and optimized with appropriate pH and temperature conditions for maximal enzyme activity. Genomic DNA was isolated from the strain and amplified the fragment by polymerase chain reaction (PCR) using gene-specific primers for protease. The fragment is then ligated into a T/A cloning vector and transformed into calcium chloridetreated competent Escherichia coli DH5 $\alpha$ cells. The plasmids were then isolated and confirmed the presence of the gene.

Results: A specific amplification of $1.1 \mathrm{~kb}$ was observed following PCR. The amplified product includes the coding sequence and a signal peptide sequence of the protease gene. After cloning with T/A cloning vector pTZ57R/T and transformed into E. coli DH5 $\alpha$ competent cells, the recombinant plasmid was selected using blue-white selection. Plasmid DNA isolated from the recombinant strains and confirmed the presence of a gene of interest using PCR and quantified by an assay for maximal protease activity. The optimum $\mathrm{pH}$ was found to be 10.1 and giving an activity of 21.566 international unit (IU)/ml, and the optimum temperature was found to be on $60^{\circ} \mathrm{C}$ giving an activity of $38.708 \mathrm{IU} / \mathrm{ml}$.

Conclusion: Amplification of protease gene by PCR isolated from Bacillus strain and optimization of pH and temperature conditions for the assessment of subtilisin Carlsberg produced by it. Subtilisin which is protein engineered can be used in commercial products such as stain cutter, dishwashing detergents, cosmetics and food processing, and contact lens cleaner.

Keywords: Bacillus subtilis, Gene amplification, Polymerase chain reaction, Protease, Subtilisin Carlsberg.

(C) 2017 The Authors. Published by Innovare Academic Sciences Pvt Ltd. This is an open access article under the CC BY license (http://creativecommons. org/licenses/by/4. 0/) DOI: http://dx.doi.org/10.22159/ajpcr.2017.v10i10.19206

\section{INTRODUCTION}

Microorganisms play an important role in industrial scale for the production of intracellular and extracellular enzymes [1,2]. Enzyme reactions are a crucial process in living cells, which act as catalysts are essential for life [3-5].

Numerous strains of Bacillus produce extracellular proteolytic enzyme which has broad specificity and an alkaline $\mathrm{pH}$ optimum. These enzymes now called as subtilisin Carlsberg was discovered by LinderstromLang and Ottesen [6] and purified by Gtintelberg and Ottesen [7]. This enzyme can be called as subtilisin A and subtilopeptidase A, and an alkali was considered to be responsible for the transformation of ovalbumin to plakalbumin [6-8] and used for the transformation of ribonuclease to ribonuclease S [9].

Bacillus subtilis which was often used for the production of most chemicals and industrial enzymes $[1,10,11]$. Proteases act in developing biopharmaceutical products which aid in cleaning contact lens and to get rid of debris [12]. It also supports in the natural healing process in skin ulceration by efficiently removing necrotic material [13].

Of all the alkalophilic microorganisms that had been screened for use in various industrial applications, members of the genus Bacillus had been found to be predominant and a prolific source of alkaline proteases. These proteases are of great importance in detergent industry due to their high thermostability and $\mathrm{pH}$ stability.

Genetic manipulation of the host bacteria had been undertaken to maximize the industrial production of the enzyme. Genes encoding protease had been cloned and sequenced from a variety of organisms, some of which are used commercially. Cloning the gene in a plasmid is one of the options available for genetic manipulation, but the more stable option seems to be chromosomal integration and expression.

Genetic manipulation of some $B$. subtilis is easier due to the relative ease in their transformation. On the other hand, industrially important organisms are not amenable to genetic transformations and are difficult to transform efficiently. Therefore, there was an increasing interest in developing methods for amplification of genes, especially those encoding protease in industrially important bacilli.

In this research, the polymerase chain reaction (PCR) amplification of putative protease genes from a putative Bacillus strain isolated from slaughterhouse soil and the optimization of the $\mathrm{pH}$ and temperature conditions for the assessment of subtilisin Carlsberg produced by it.

\section{METHODS}

\section{Screening for protease producers}

Soil sample was collected from slaughterhouse and was serially diluted, $100 \mu \mathrm{l}$ of $10^{-3}$ dilution of each sample was spread plated on LuriaBertani agar plates. Milk powder and agar were dissolved in about $60 \mathrm{ml}$ and in $40 \mathrm{ml}$ of distilled water, respectively, autoclaved at 15lbs pressure, $121^{\circ} \mathrm{C}$ for $15-20$ minutes. The two solutions were then mixed well, added to Petri plates, and allowed to cool under sterile conditions. The plates were then incubated at $37^{\circ} \mathrm{C}$ overnight. Colonies resembling Bacillus were inoculated into LB broth and subjected to heat shock treatment at $80^{\circ} \mathrm{C}$ for 10 minutes. A loopful of culture suspension was streaked onto $\mathrm{LB}$ agar plates and incubated at $37^{\circ} \mathrm{C}$ overnight. A volume 
of $50 \mu \mathrm{l}$ of culture suspension was drop plated onto milk agar plates, incubated for $18 \mathrm{hrs}$ at $37^{\circ} \mathrm{C}$ and observed in halo formation (indicative of milk protein consumption by the bacteria).

\section{Protease assay}

Protease activity was measured by tyrosine residue, released by the digestion of casein, which was used as the substrate. The tyrosine or other aromatic residues react with Folin-Ciocalteau's phenol reagent under alkaline conditions to give blue color. The absorbance was measured at $660 \mathrm{~nm}$ [14].

\section{Culture}

A volume of $1 \mathrm{ml}$ of the overnight grown culture of DGVP2 was inoculated into $50 \mathrm{ml}$ of protease production broth.

\section{Effect of $\mathrm{pH}$ on protease production}

The effect of $\mathrm{pH}$ on alkaline protease production from $B$. subtilis under the study was carried out using different $\mathrm{pH}$ like 9-10.5. The optimization media with the above $\mathrm{pH}$ was inoculated with the test sample and the protease assay was done after $24 \mathrm{hrs}$. The best $\mathrm{pH}$ was concluded by reading the absorbance at $660 \mathrm{~nm}$.

\section{Effect of temperature on protease production}

The effect of temperature on protease production was studied by taking various temperatures such as $16^{\circ} \mathrm{C}, 37^{\circ} \mathrm{C}, 50^{\circ} \mathrm{C}, 60^{\circ} \mathrm{C}$, and $90^{\circ} \mathrm{C}$. The optimization media was inoculated with the test sample at different temperatures and the protease assay was done after $24 \mathrm{hrs}$. The solutions were centrifuged individually at $3000 \mathrm{rpm}$ at room temperature for 10 minutes and the supernatant was used for color development.

Activity per ml=Abs (test)-Abs (EB)*120/0.276*1/1000*V*Dilution factor

where Abs (test) $=A$ bsorbance of test sample at $660 \mathrm{~nm}$

Abs (EB)=Absorbance of enzyme blank at $660 \mathrm{~nm}$

$120 / 0.276=120 \mu \mathrm{g}$ of tyrosine give approximately 0.276 OD

$\mathrm{V}=\mathrm{The}$ total volume of the reaction mixture

$1 / 1000=$ The conversion factor for the microgram to milligram of tyrosine. $\mathrm{DF}=$ Dilution factor.

\section{Isolation of genomic DNA}

For cells with rigid cell wall, disruption usually requires extraction buffer which contains detergent. CTAB is commonly used for this purpose. The extraction buffer also contains reducing agent ( $\beta$-mercaptoethanol) and a chelating agent (ethylenediaminetetraacetic acid). This helps to inactivate nucleases that are released from the cell and can cause serious degradation of the genomic DNA. Keeping the reactions cold, when possible can minimize their effects. Phenolic compounds may also be released on disruption of tissues and these may interfere with subsequent uses of the DNA (e.g., if it is to be used in the PCR). Polyvinylpyrrolidone can be added to the extraction buffer to remove phenolic compounds. Phenol extraction can be used to remove any traces of proteins and the genomic DNA can be precipitated using either ethanol or isopropanol. Precipitated DNA can be hooked out of the solution or collected by centrifugation. The DNA isolation was carried out following the methodology of Saghai-Maroof et al. [15].

\section{PCR}

The PCR master mix was prepared and $50 \mu$ of the reaction mix was aliquoted in 2 PCR tubes ( 1 experiment tube and 1 negative control). Then, $1 \mu \mathrm{l}$ of the template DNA was added at the end of the experiment tube alone. It was vortexed briefly and spun down for 3 seconds. The amplification reaction was carried out in a thermal cycler. A volume of 30-35 L of the amplified DNA from the reaction mix was removed and analyzed on $1 \%$ agarose gel. $1 \mathrm{~kb}$ DNA molecular marker was also loaded in one of the wells to ensure the size of the amplified PCR product. The entire product was repeated for the second time using high-fidelity Taq polymerase and the respective $\times 10$ assay buffer to ensure avoidance of mutations.

\section{Agarose gel electrophoresis}

To clone the gene into the vector, PCR product was separated and purified in preparative agarose gel electrophoresis following the method described by Sambrook [16].

\section{Gel elution}

The gel portion containing the amplified PCR product was cut carefully using a sterile blade and stored in a microfuge tube at $-20^{\circ} \mathrm{C}$. Care was taken not to switch on the UV transilluminator for long, to prevent mutations. The gel was then crushed well with a $1000 \mu \mathrm{l}$ tip. The volume of the gel contents was assumed to be $40 \mu \mathrm{l}$. To this, $360 \mu \mathrm{l}$ of sterile Milli-Q water was added followed by $400 \mu$ of tris-saturated phenol. The tubes were then stored for 10 minutes at $-80^{\circ} \mathrm{C}$. The tubes were then removed, thawed, and spun in a centrifuge for 5 minutes at 10,000 rpm. The supernatant was transferred to a fresh microfuge tube and to this $400 \mu \mathrm{l}$ of chloroform was added. The contents were centrifuged at $10,000 \mathrm{rpm}$ for 5 minutes. $250-300 \mu \mathrm{l}$ of the supernatant was taken in a fresh microfuge tube, to this about $25-30 \mu \mathrm{l}$ of $3 \mathrm{M}$ sodium acetate was added, followed by 625-800 $\mu \mathrm{l}$ cold 100 ethanol. Tubes were stored at $-20^{\circ} \mathrm{C}$ for 30 minutes. The contents were centrifuged at $12,000 \mathrm{rpm}$ for 5 minutes. The pellet was dried and resuspended in $25 \mu \mathrm{l}$ of sterile Milli-Q water. The eluted DNA was stored at $-20^{\circ} \mathrm{C}$. The amount of DNA obtained was quantified either visually by running an aliquot on an agarose gel or by UV absorbance using the following equation [16].

DNA $(\mu \mathrm{g} / \mathrm{ml})=$ OD. $(\mathrm{A} 260 \mathrm{~nm}) \times$ Dilution factor $\times 50$

\section{Ligation using $\mathrm{T} / \mathrm{A}$ cloning vector}

The T/A cloning method allows convenient ligation of PCR amplified products, which possess excess Adenines at their ends, to a vector provided with dT overhangs on both ends. The vector pTZ57 $\mathrm{R} / \mathrm{T}$ has been precleaved with Eco321 and treated with terminal deoxynucleotidyl transferase to create 3 ' ddT overhangs at both ends. Ligation with PCR amplified fragment produces a circular molecule with two nicks and this can be transformed with high efficiency.

The ligation mix was set up as follows. The mixture was incubated at $37^{\circ} \mathrm{C}$ for 5 minutes and this was used for the transformation reaction.

\section{Competent cell preparation}

DH5 $\alpha$ strain of Escherichia coli was revived from $-80^{\circ} \mathrm{C}$ by plating on LB agar plate without antibiotics and incubated at $37^{\circ} \mathrm{C}$ overnight. A single colony from this plate was picked and inoculated into $5 \mathrm{ml}$ of LB broth and incubated overnight at $37^{\circ} \mathrm{C}$ with agitation. A volume of $500 \mu \mathrm{l}$ of the overnight culture was inoculated into $50 \mathrm{ml}$ of LB broth and incubated at $37^{\circ} \mathrm{C}$ with agitation until the OD was 0.4 . The cells were chilled on ice for 20 minutes and transferred to pre-chilled sterile centrifuge tubes. The tubes were centrifuged at $4^{\circ} \mathrm{C}, 6000 \mathrm{rpm}$ for 5 minutes to pellet the cells. The cells were resuspended gently in $20 \mathrm{ml}$ of $100 \mathrm{mM}$ calcium chloride incubated on ice for 45 minutes. The cells were resuspended gently in $20 \mathrm{ml}$ of $100 \mathrm{mM}$ calcium chloride incubated on ice for 45 minutes. The cells were centrifuged at $6000 \mathrm{rpm}$ at $4^{\circ} \mathrm{C}$, for 10 minutes, The supernatant was discarded and the cells were resuspended in $1700 \mu \mathrm{l} 37^{\circ} \mathrm{C}$ with agitation of $100 \mathrm{mM}$ calcium chloride incubated on ice for 45 minutes. The cells were centrifuged at $6000 \mathrm{rpm}$ at $4^{\circ} \mathrm{C}$, for 10 minutes. The supernatant was discarded and the cells were resuspended in $1700 \mu \mathrm{l} 37^{\circ} \mathrm{C}$ with agitation of $100 \mathrm{mM}$ calcium chloride $+300 \mu \mathrm{l}$ of sterile glycerol solution. 100 of the cells were aliquoted into cryotubes and stored at $-80^{\circ} \mathrm{C}$.

\section{Transformation of competent cells with the ligation mix}

Transformation of competent bacterial cells was carried out as described by Hanahan [17]. Competent cells were thawed from $-80^{\circ} \mathrm{C}$ deep freeze. A volume of $5 \mu$ l of the ligation mix was added to the $100 \mu$ laliquot of the competent cells. The vials were tapped gently and incubated on ice for 30 minutes. The cells were given a heat shock by placing them for 
90 seconds in a water bath set at $42^{\circ} \mathrm{C}$. The tubes were immediately placed on ice for 5 minutes. A volume of $100 \mu \mathrm{l}$ of the cells were then plated on LB agar plates that had been pre-incubated with $80 \mu$ of X-Gal and $8 \mu \mathrm{l}$ of IPTG and contained ampicillin. The plates were incubated at $37^{\circ} \mathrm{C}$ overnight and observed for the appearance of colonies pUC19 was transformed into E. coli $\mathrm{DH} 5 \alpha$ cells to determine the transformation efficiency (TE) of competent cells. Transformation efficiently of the competent cells is calculated using the following formula:

TE of competent cells:

$\mathrm{TE}=$ Number of colonies $/ \mathrm{ml} / \mu \mathrm{g}$ of plasmid DNA

\section{Identification of recombinants using blue-white selection} $\alpha$-complementation

Many of the vectors in current use (e.g., the pUC series) carry a short segment of $E$. coli DNA that contains the regulatory sequences and t-coding information for the first 146 amino acids of the betagalactosidase gene (lacZ). Embedded in this coding region is a polycloning site that does not disrupt the reading frame but results in the harmless interpolation of a small number of amino acids into the amino-terminal fragment of beta-galactosidase. Vectors are these types are used in host cells (e.g., DH $5 \alpha$ ) that code for the carboxy terminal portion of beta-galactosidase. Although neither the hostencoded nor the plasmid-encoded fragments are themselves active, they can associate to from an enzymatic active protein. This type of complementation in which deletion mutants of the operator proximal segment of the lacZ are complemented by beta-galactosidase - negative mutants that have the operator - proximal region intact, is called $\alpha$-complementation.

The lac + bacteria that result from $\alpha$-complementation is easily recognized because they form blue colonies in the presence of chromogenic substrate X-Gal (also abbreviated BCIG for 5-bromo4-chloro-3-indolyl- $\beta$-D-galactopyranoside). However, insertion of a fragment of a foreign DNA into the polycloning site almost invariably results in the production of an amino-terminal fragment that is capable of $\alpha$-complementation. Bacteria carrying recombinant plasmids therefore form white colonies. This method identification therefore known as blue-white selection of recombinants. This development of this simple color test has greatly simplified the identification of recombinants constructed in plasmid vectors of this type. It is easily possible to screen many thousands of colonies that carry putative recombinant plasmids. The structure of these plasmids is then verified by restriction analysis of mini preparation of plasmid DNA.

The recombinant clones, after transformation, were thus identified by blue-white. Blue colonies indicated the absence of the desired gene. White colonies indicated the presence of insert DNA and 10 of them were selected and streaked into LB ampicillin plates to obtain pure cultures. A single colony from each of the recombinants was inoculated into $5 \mathrm{ml}$ of LB broth containing ampicillin $(100 \mu \mathrm{g} / \mathrm{ml})$ and incubated at $37^{\circ} \mathrm{C}$ with agitation, overnight. A volume of $5 \mathrm{ml}$ of the overnight grown culture was used for plasmid preparation.

\section{PCR amplification to confirm the presence of the gene}

The isolated plasmid DNA was used as a template to set up a PCR reaction for the confirmation of the presence of the gene. PCR using Sig $\mathrm{F}$ and ProtR primers to confirm the presence of the gene. The reactions were set up in PCR tubes and given a short spin before placing them in the thermal cycler. The conditions of PCR reaction are the same as mentioned previously. The samples were subjected to agarose gel electrophoresis and the gel was visualized under UV transilluminator to check for amplification.

\section{RESULTS}

\section{Screening for protease producers}

The three soil sample isolated were serially diluted and plated on LB agar plates. Five of the colonies that morphologically resembled bacilli were subjected to heat shock treatment. The LB broth inoculated with these five colonies were incubated at $80^{\circ} \mathrm{C}$ for ten minutes and plated on LB agar plates. Colonies were observed only in two of the five LB agar plates indicating that they could be bacilli. Overnight broth cultures of these five strains of DGVP2 were used for plating on milk agar plates. One of these plates showed a significant halo formation indicating protease production.

\section{Protease assays}

Optimization of $\mathrm{pH}$

The assays were performed over a range of $\mathrm{pH}$, provided by the buffers $(\mathrm{pH} 9.0,9.5,10.1$, and 10.6$)$ at $37^{\circ} \mathrm{C}$ represented in Tables 1 and 2 (Graph 1).

\section{Optimization of temperature}

The assays were performed over a range of temperatures $\left(16^{\circ} \mathrm{C}\right.$, $37^{\circ} \mathrm{C}, 50^{\circ} \mathrm{C}, 60^{\circ} \mathrm{C}$, and $90^{\circ} \mathrm{C}$ ) at $\mathrm{pH} 10.1$ represented in Tables 3 and 4 (Graph 2).

The maximal activity was when the enzyme was subjected to incubation at the temperature of $60^{\circ} \mathrm{C}$. On the basis of the assays, it is evident that the maximal activity was attained on day 6 , while utilizing a buffer at $\mathrm{pH} 10.1$ and incubation temperature at $37^{\circ} \mathrm{C}$.

Table 1: OD value at different $\mathrm{pH}$

\begin{tabular}{llllll}
\hline $\begin{array}{l}\text { Day of assay } \\
\text { Dilution factor } \\
\text { OD }\end{array}$ & 3 & 4 & 5 & 6 & 7 \\
pH 9 & & & 11 & 16 & 7 \\
$\quad$ Enzyme blank & 0.387 & 0.177 & 0.161 & 0.207 & 0.249 \\
$\quad$ Test & 0.508 & 1.553 & 0.404 & 0.653 & 1.195 \\
pH 9.5 & & & & & \\
$\quad$ Enzyme blank & 0.220 & 0.257 & 0.163 & 0.265 & 0.28 \\
$\quad$ Test & 0.615 & 1.256 & 0.406 & 0.562 & 1.208 \\
pH 10.1 & & & & & \\
$\quad$ Enzyme blank & 0.322 & 0.193 & 0.177 & 0.161 & 0.204 \\
$\quad$ Test & 0.498 & 1.608 & 0.438 & 0.491 & 1.211 \\
pH 10.5 & & & & & \\
$\quad$ Enzyme blank & 0.296 & 0.198 & 0.175 & 0.160 & 0.251 \\
$\quad$ Test & 0.472 & 1.177 & 0.472 & 0.613 & 1.470 \\
\hline
\end{tabular}

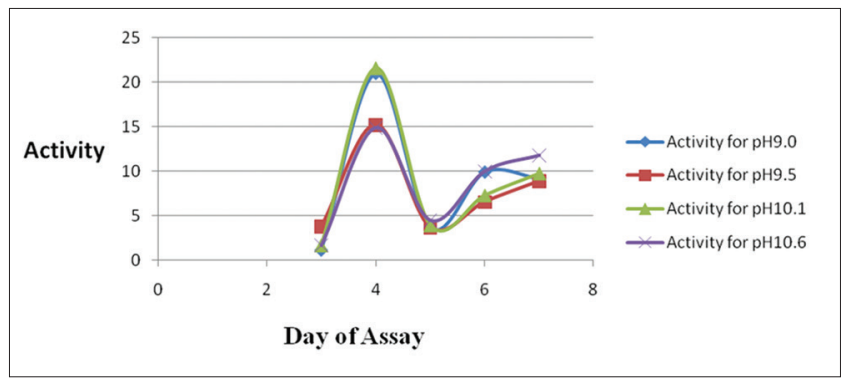

Graph 1: Optimization of $\mathrm{pH}$

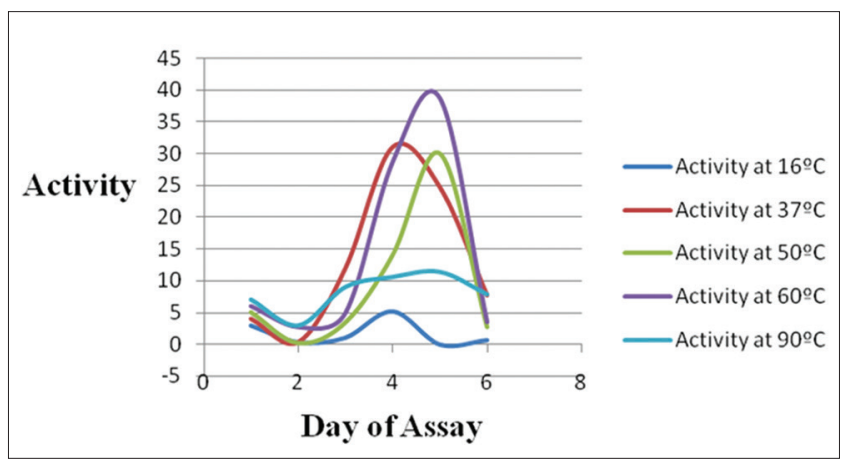

Graph 2: Optimization of temperature 
Table 2: Calculations for enzyme activity

\begin{tabular}{lllll}
\hline Day of assay & Activity for $\mathbf{p H} \mathbf{9 . 0}$ & Activity for $\mathbf{p H} \mathbf{9 . 5}$ & Activity for $\mathbf{p H} \mathbf{1 0 . 1}$ & Activity for $\mathbf{p H} \mathbf{1 0 . 6}$ \\
\hline 3 & 1.173 & 3.831 & 1.707 & 1.707 \\
4 & 20.972 & 15.226 & 21.566 & 14.92 \\
5 & 3.703 & 3.705 & 3.97 & 4.526 \\
6 & 9.909 & 6.584 & 7.31 & 10.04 \\
7 & 9.175 & 8.913 & 9.767 & 11.8233 \\
\hline
\end{tabular}

Table 3: OD value at different $\mathrm{pH}$

\begin{tabular}{|c|c|c|c|c|c|}
\hline Day of assay & 3 & 4 & 5 & 6 & 7 \\
\hline Dilution factor & 5 & 13 & 11 & 16 & 7 \\
\hline \multicolumn{6}{|l|}{ OD } \\
\hline \multicolumn{6}{|l|}{$16^{\circ} \mathrm{C}$} \\
\hline Enzyme blank & 0.344 & 0.328 & 0.307 & 0.153 & 0.331 \\
\hline Test & 0.397 & 0.347 & 0.315 & 0.275 & 0.641 \\
\hline \multicolumn{6}{|l|}{$37^{\circ} \mathrm{C}$} \\
\hline Enzyme blank & 0.453 & 0.230 & 0.293 & 0.330 & 0.257 \\
\hline Test & 0.610 & 0.893 & 0.515 & 0.551 & 1.181 \\
\hline \multicolumn{6}{|l|}{$50^{\circ} \mathrm{C}$} \\
\hline Enzyme blank & 0.388 & 0.216 & 0.388 & 0.151 & 0.303 \\
\hline Test & 1.142 & 1.936 & 1.308 & 1.444 & 1.387 \\
\hline \multicolumn{6}{|l|}{$60^{\circ} \mathrm{C}$} \\
\hline Enzyme blank & 0.529 & 0.251 & 0.255 & 0.150 & 0.219 \\
\hline Test & 1.845 & 1.621 & 2.197 & 1.896 & 1.386 \\
\hline \multicolumn{6}{|l|}{$90^{\circ} \mathrm{C}$} \\
\hline Enzyme blank & 0.485 & 0.196 & 0.243 & 0.167 & 0.296 \\
\hline Test & 0.587 & 0.623 & 0.417 & 0.324 & 1.102 \\
\hline
\end{tabular}

\section{PCR amplification}

Genomic DNA isolated from the given strain was used as a template for PCR for amplification protease gene. An amplified DNA fragment corresponding to $1.1 \mathrm{~kb}$, as expected, was observed on the agarose gel. This DNA fragment was gel eluted, purified, and reserved for the subsequent cloning experiment.

\section{$\mathrm{T} / \mathrm{A}$ cloning of the protease gene}

The $1.1 \mathrm{~kb}$ PCR amplified product was ligated into the T/A cloning vector and transformed into E. coli DH5 $\alpha$ whose TE using pUC19 was found to be $10^{5}$ cells $/ \mathrm{ml}$. The E. coli DH $5 \alpha$ used for competent cell preparation were initially checked in its growth on LB agar medium containing ampicillin. As there was no growth, this indicates that the strain was not contaminated with ampicillin-resistant strains.

Two white colonies were streaked onto LB agar plates containing ampicillin, X-Gal, and IPTG.

Plasmids isolated from the two white colonies were subjected to PCR causing signal forward and protease-reverse primers to confirm the presence of the gene in the recombinants; specific amplification was observed in both cases.

\section{DISCUSSION}

Bacillus species are the dominant bacterial workhouses in microbial fermentation. The capacity of selected Bacillus strains to produce and secrete large quantities (20-25 g/L) of extracellular enzymes has placed them among the most important industrial enzyme producers. Of all proteases, alkaline protease produced by bacilli is of great importance due to their high thermostability and $\mathrm{pH}$ stability [18]. In this study, slaughterhouse soil samples were screened for protease producers and a putative Bacillus strain was identified.

Primers were designed based on the nucleotide sequence of Bacillus licheniformis (Accession number X91261) available in the National Center for Biotechnology Information (NCBI) database. An expected size of $1.1 \mathrm{~kb}$ DNA fragment was amplified with the primers using the isolated genomic DNA from the selected putative Bacillus strain. The technique of PCR has been used widely to clone the gene encoding protease from a variety of bacteria. The amplified product was cloned into a T/A cloning vector and transformed into E. coli. The present state of knowledge of protein export in Bacillus species is still relatively poor. Therefore, the most thoroughly characterized export systems of E. coli [19] are utilized for the expression of industrially important enzymes such as alkaline proteases. The recombinants of $E$. coli harboring the protease gene from Erwinia chrysanthemi and from Pseudomonas aeurginosa [20] have been shown to secrete recombinant proteins.

Bacteriocin release proteins (BRPs) can be used for the release of heterologous protein from the E. coli cytoplasm into the culture medium. The gene for a highly thermostable alkaline protease was cloned from Bacillus stearothermphilus F1 by the PCR; The recombinant F1 protease was efficiently excreted into the culture medium using E. coli XL1-Blue harboring two vectors: pTrcHis bearing the protease gene and pJL3 containing the BRPs [21]. It was reported the cloning and sequencing of a serine protease gene from a thermophillic Bacillus species and its expression in E. coli [22].

In general, alkaline protease production is found to be maximum at pH 9-13 [14]. The protease from Alcaligenes sp. was optimized for its maximum production and the effect of metal ions on its activity was also studied. The enzyme was purified using ammonium sulfate precipitation and it has been effectively used with the commercial detergents [23]. The 3D structure of serine protease from B. subtilis sp. was evaluated using different bioinformatics tools and implied that this enzyme is highly thermostable as well as having an excellent solubility in water [24]. Bacillus which is an important species for enzyme production, especially protease. Hence, the enzyme is optimized and studied in immobilization and fermentor conditions to yield maximum production. The enzyme is highly stable in entrapment and fermentation method [25]. It is reported that Bacillus spp. has shown antifungal activity in particular against Candida albicans. The maximum antifungal activity was observed on the production of Bacillus on Yeast Mannitol Agar (YMA) culture medium [26]. Both temperature and $\mathrm{pH}$ plays an important role in deciding the utility of the protease in detergents. Therefore, a temperature range of $16-90^{\circ} \mathrm{C}$ was chosen to assay the activity of the protease. The highest activity was recorded as 38.708 international units (IU) $/ \mathrm{ml}$, at the temperature of $60^{\circ} \mathrm{C}$. This indicates the thermal stability of the enzyme. The overall maximal activity was recorded as $38.708 \mathrm{IU} / \mathrm{ml}$, at the temperature of $60^{\circ} \mathrm{C}$, while using a buffer at $\mathrm{pH} 10.1$.

\section{CONCLUSION}

A putative Bacillus strain showing a halo on protease-screening medium was isolated from one of the slaughterhouse samples. Primers were designed based on the coding region of the protease gene of B. licheniformis (NCBI Accession No. X91261). A specific amplification of $1.1 \mathrm{~kb}$ was observed following PCR. The amplified product included the coding sequence and the signal peptide sequence of the protease gene. The amplified product was cloned into T/A cloning vector pTZ57R/T and transformed into E. coli DH5 $\alpha$ competent cell. E. coli strains containing the recombinant plasmid were selected using bluewhite selection. Plasmid DNA isolated from the recombinant strains was diluted and used as a template for PCR to confirm the presence of gene of interest. Protease production of the strain was quantified by an 
Table 4: Calculations for enzyme activity

\begin{tabular}{|c|c|c|c|c|c|}
\hline Day of Assay & Activity at $16^{\circ} \mathrm{C}$ & Activity at $37^{\circ} \mathrm{C}$ & Activity at $50^{\circ} \mathrm{C}$ & Activity at $60^{\circ} \mathrm{C}$ & Activity at $90^{\circ} \mathrm{C}$ \\
\hline 3 & 0.367 & 1.087 & 5.22 & 9.117. & 0.70 \\
\hline 4 & 0.342 & 11.942 & 30.982 & 24.67 & 7.69 \\
\hline 5 & 0.122 & 3.38 & 14.02 & 30.05 & 2.65 \\
\hline 6 & 2.704 & 4.899 & 28.665 & 38.708 & 3.480 \\
\hline 7 & 2.942 & 8.962 & 10.513 & 11.318 & 7.817 \\
\hline
\end{tabular}

assay. The $\mathrm{pH}$ and temperature conditions of the assay were optimized for maximal protease activity. The optimum $\mathrm{pH}$ was found to be 10.1 giving an activity of $21.566 \mathrm{IU} / \mathrm{ml}$; and the optimum temperature was found to be at $60^{\circ} \mathrm{C}$ giving an activity of $38.708 \mathrm{IU} / \mathrm{ml}$.

\section{REFERENCES}

1. Gupta R, Beg QK, Lorenz P. Bacterial alkaline proteases: Molecular approaches and industrial applications. Appl Microbiol Biotechnol 2002;59:15-32.

2. Moo-Young M, Chisti Y. Biochemical engineering in biotechnology. Pure Appl Chem 1994;66:117-36.

3. Sierecka JK. Purification and partial characterization of a neutral protease from a virulent strain of Bacillus cereus. Int J Biochem Cell Biol 1998;30(5):579-95.

4. Johnson L. Symmetry at the molecular level in biology. Eur Rev 2005;13:77-95.

5. Pingoud A, Fuxreiter M, Pingoud V, Wende W. Type II restriction endonucleases: Structure and mechanism. Cell Mol Life Sci 2005;62(6):685-707.

6. Linderstrom-Land K, Ottesen M. A new protein from ovalbumin. Nature 1947;159(4050):807.

7. Guntelberg AV, Ottesen M. Comptes-rendus Des Travaux Du Laboratoire Carlsberg journal 1960;32:63.

8. Linderstrom-Lang K, Schellman JA. Protein structure and enzymatic activity. In: Lardy H, Myrback K ed. The Enzymes $2^{\text {nd }}$ ed. New York: Academic Press 1959;443-510.

9. Richards FM. On an active intermediate produced during the digestion of ribonuclease by subtilisin. C R Trav Lab Carlsberg Chim 1955;29(17-19):329-46.

10. Esakkiraj P, Immanuel G, Sowmya SM, Iyapparaj P, Palavesam A. Evaluation of protease-producing ability of fish gut isolate Bacillus cereus for aqua feed. Food Bioprocess Technol 2009;2:383-90.

11. Chu WH. Optimization of extracellular alkaline protease production from species of Bacillus. J Ind Microbiol Biotechnol 2007;34(3):241-5.

12. Anwar A, Saleemuddin M. Alkaline protease from Spilosoma obliqua: Potential applications in bio-formulations. Biotechnol Appl Biochem 2000;31:85-9.

13. Sjodahl J, Emmer A, Vincent J, Roeraade J. Characterization of proteinases from antarctic krill (Euphausia superba). Protein Exp Purif 2002;26:153-61.
14. Saghai-Maroof MA, Soliman KM, Jorgensen RA, Allard RW. Ribosomal DNA spacer-length polymorphisms in barley: Mendelian inheritance, chromosomal location, and population dynamics. Proc Natl Acad Sci U S A 1984;81(24):8014-8.

15. Sambrook J, Michael R. Green, Molecular Cloning - A Laboratory Manual. New York: Cold Spring Harbor Laboratory Press; 1989.

16. Hanahan D, Jessee J, Bloom FR. Plasmid transformation of Escherichia coli and other bacteria. Methods Enzymol 1991;204:63-113.

17. Naidu KS, Devi KL. Optimization of thermostable alkaline protease from species of Bacillus using rice bran. Afr J Biotechnol 2005;4(7):724-6.

18. Simonen M, Palva I. Protein secretion in Bacillue species. Microbiol Rev 1993;57(1):109-37.

19. Atsumi Y, Yamamoto S, Morihara S, Fukushima J, Takeuchi H, Mizuki $\mathrm{N}$, et al. Cloning and expression of the alkaline proteinase gene from Pseudomona aeruginosa IFO 3455. J Bacteriol 1989;171(9):5173-5.

20. Fu Z, Hamid SB, Razak CN, Basri M, Salleh AB, Rahman RN. Secretory expression in Escherichia coli and single-step purification of a heat-stable alkaline protease. Protein Expr Purif 2003;28(1):63-8.

21. Saul DJ, Bryce M, Ronnie HM, Peter LB. Cloning and sequencing of a serine proteinase gene from a thermophillic Bacillus species and its expression in E. coli. Appl Environ Microbiol 1994;60(11):3981-8.

22. Sellami-Kamoun A, Haddar A, El-Hadj Ali N, Ghorbel-Frikha B, Kanoun S, Nasri M. Stability of thermostable alkaline protease from Bacillus licheniformis RPI in commercial solid laundry detergent formulations. Elsevier Microb Res 2006;163:299-306.

23. Aishwarya M, Kumari S, Sivasubramanian A, Muthuraman MS. Production, characterization and purification of alkaline protease from Alcaligenes sp., and its application in detergent industry. Asian J Pharm Clin Res 2013;6(4):151-5.

24. Irajie C, Mohkam M, Nezafat N, Mohammadi F, Ghasemi Y. In silico analysis of nattokinase from Bacillus subtilis sp natto. Int J Pharm Clin Res 2017;9(4):286-92.

25. Vijayalakshmi S, Ranjitha J, Rajeswari SV. Enzyme production ability by Bacillus subtilis and Bacillus licheniformis - A comparative study. Asian J Pharm Clin Res 2013;6(4):29-32.

26. Balouiri M, Bouhdid S, Harki EH, Sadiki M, Ouedrhiri W, Ibnsouda SK. Antifungal activity of Bacillus spp. Isolated from Calotropis procera ait. Rhizosphere against Candida albicans. Asian J Pharm Clin Res 2015;8(2):213-7. 